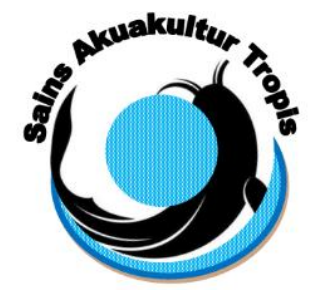

\author{
Jurnal Sains Akuakultur Tropis \\ Departemen Akuakultur \\ Fakultas Perikanan dan IImu Kelautan - Universitas Diponegoro \\ JI. Prof. Soedarto, SH, Tembalang, Semarang 50275 \\ Telp. (024) 7474698, Fax.: (024) 7474698 \\ Email: sainsakuakulturtropis@gmail.com, sainsakuakulturtropis@undip.ac.id
}

\title{
PENGARUH SILASE CACING TANAH (Lumbricus Sp.) SEBAGAI SUBSTITUSI TEPUNG IKAN DALAM PAKAN BUATAN TERHADAP PEMANFAATAN PAKAN DAN PERTUMBUHAN IKAN BAWAL AIR TAWAR ( $\underline{\text { Colossoma macropomum }}$ )
}

\author{
The Effect of Earthworm Silage (Lumbricus sp.) as Fish Meal Substitution in Artificial Feeds on the Utilization \\ and Growth of Red Belly Fish (Colossoma macropomum)
}

\section{Siti Maryam, Sri Hastuti*), Diana Rachmawati}

Departemen Akuakultur,

Fakultas Perikanan dan Ilmu Kelautan,

J1. Prof. Soedarto, SH, Tembalang, Semarang, Jawa Tengah -50275, Telp/Fax. +62247474698

* Corresponding author: hastuti_hastuti@yahoo.com

\begin{abstract}
ABSTRAK
Pertumbuhan ikan bawal meningkat jika kandungan protein sesuai dengan kebutuhan dan mempunyai profil asam amino hampir mirip dengan tubuh ikan. Harga pakan terus meningkat tanpa diiringi dengan kenaikan harga ikan. Hal tersebut menjadikan pengusaha budidaya perikanan terus berinovasi mencari alternatif bahan lokal. Salah satu alternatif yang digunakan yaitu silase cacing tanah. Penelitian ini bertujuan untuk mengkaji pengaruh silase cacing tanah (Lumbricus sp.) sebagai substitusi tepung ikan dalam pakan buatan terhadap pemanfaatan pakan dan pertumbuhan ikan bawal tawar serta menentukan komposisi terbaik silase cacing tanah (Lumbricus sp.) sebagai substitusi tepung ikan dalam pakan buatan. Ikan uji yang digunakan yaitu benih ikan bawal tawar dengan bobot tubuh rata-rata 2,98 $\pm 0,01$ g/ekor, dipelihara selama 35 hari, padat tebar 1 ekor/L. Pakan yang digunakan berbentuk pellet dengan protein $31 \%$ diberikan secara at satiation dua kali sehari. Eksperimen menggunakan rancangan acak lengkap (RAL) 4 perlakuan dan 3 ulangan, substitusi silase cacing tanah yang digunakan yaitu perlakuan A $(0 \%)$, B $(25 \%)$, C $(50 \%)$ dan D $(75 \%)$. Variabel yang diamati meliputi total konsumsi pakan (TKP), efisiensi pemanfaatan pakan (EPP), rasio konversi pakan (FCR), protein efisiensi rasio (PER), laju pertumbuhan relatif (RGR) dan kelulushidupan. Hasil penelitian menunjukkan bahwa silase cacing tanah sebagai substitusi tepung ikan memberikan pengaruh nyata $(\mathrm{P}<0,05)$ terhadap TKP, EPP, FCR, PER dan RGR, namun tidak berpengaruh nyata $(\mathrm{P}>0,05)$ terhadap kelulushidupan. Komposisi terbaik silase cacing tanah sebagai substitusi tepung ikan yaitu perlakuan C 50\% tepung ikan dan $50 \%$ silase cacing tanah memberikan nilai TKP 145,13 $\pm 2,90 \mathrm{~g}$, EPP

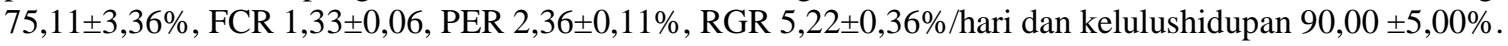

Kata kunci: Bawal Air Tawar, Silase Cacing Tanah, Pakan, Pertumbuhan

\section{ABSTRACT}

The growth of red belly fish quickly increases if the protein content is in accordance with the needs of the fish and has an amino acid profile that matches or is almost similar to the body of the fish. Feed prices continue to increase without being accompanied by increases in fish prices. This makes the aquaculture entrepreneurs continue to innovate in search of alternative feed from local ingredients. One of alternatives that can be used is earthworm silage. This research aimed to review the influence of earthworm silage as a fish meal substitution in artificial feed for feed utilization and growth red belly fish (C. macropamum) and to determine the best composition of silage earthworm (Lumbricus sp.) as a substitute for fish meal in artificial feed.The experimental fish juvenile of (C. macropamum) with an average individual body weight of 2,98 $\pm 0,01 \mathrm{~g} /$ fish, maintained on 35 days with the density of $1 \mathrm{fish} / \mathrm{L}$. Artificial feed with contains of $31 \%$ protein was given at satiation twice a day. The experiment used a completely randomized design with 4 treatment and 3 repetitions. The composition of silage earthworm meal used treatment $A(0 \%), B(25 \%), C(50 \%)$ and $D(75 \%)$. The variable measured were total feed consumption (TKP), feed utilization efficiency (EPP), feed consumtion rate $(F C R)$, protein efficiency ratio $(P E R)$, relative growth rate $(R G R)$ and survival rate $(S R)$. The results show that earthworm silage as a substitute for fish meal had a significant effect $(P<0.05)$ to TKP, EPP,FCR, PER and RGR. However, not significant effect $(P$ 
$<0,05)$ to SR. The best composition in the study is $C$ with TKP 145,13 $\pm 2,90 \mathrm{~g}$, EPP 75,11 $\pm 3,36 \%, F C R 1,33 \pm$ 0,06, PER 2,36 $\pm 0,11 \%, R G R 5,22 \pm 0,36 \%$ /day and survival rate 90,00 $\pm 5,00 \%$.

Keywords: Red Belly Fish, Silage Earthworm Meal, Feed, Growth

Article Received: 18-12-2018; Accepted: 28-02-2019

\section{PENDAHULUAN}

Ikan bawal air tawar (Colossoma macropomum) merupakan komoditas perikanan yang memiliki nilai ekonomis cukup tinggi. Pada mulanya ikan bawal air tawar diperdagangkan sebagai ikan hias, namun karena memiliki pertumbuhan yang relatif cepat, nafsu makan yang baik, tidak terlalu sulit dibudidayakan karena bersifat omnivor (pemakan segala), relatif tahan terhadap penyakit, dan memiliki rasa daging yang enak, maka masyarakat menjadikan ikan tersebut sebagai ikan konsumsi (Utami et al., 2012). Keistimewaan tersebut membuat banyak petani ikan membudidayakan dan menjadi peluang usaha yang menjanjikan dalam peluang usaha budidaya perikanan (Kardana et al., 2012).

Masalah utama yang dihadapi dalam budidaya ikan bawal air tawar antara lain ketersediaan pakan yang cukup dalam jumlah dan kualitasnya untuk mendukung pertumbuhan yang maksimal. Ikan dapat tumbuh dengan maksimal apabila pakan dapat dimafaatkan secara efisien dan mempunyai profil asam amino lengkap serta sesuai atau mirip dengan tubuh ikan. Menurut Santoso dan Agusmansyah (2011), pakan merupakan komponen produksi terbesar $60-70 \%$ dari biaya produksi budidaya ikan. Saat ini harga pakan terus meningkat tanpa diiringi dengan kenaikan harga ikan. Hal tersebut menjadikan para pengusaha budidaya perikanan terus berinovasi mencari pakan alternatif dari bahan lokal yang memilki kualitas tinggi. Sehubung dengan hal tersebut maka diperlukan substitusi bahan pakan ikan dengan sumber protein hewani dari tepung ikan dengan sumber protein hewani dari silase cacing tanah.

Substitusi tepung ikan dengan silase cacing tanah merupakan upaya memanfaakan bahan baku lokal yang tidak bersaing dengan kebutuhan pangan manusia, mudah dibudidayakan, efisien dan murah yaitu dengan cara memanfaatkan limbah seperti limbah bekas budidaya jamur sehingga dapat mengurai bahan organik dan dapat menjaga keseimbangan lingkungan. Selain itu cacing tanah juga mempunyai kandungan gizi yang tinggi dan profil asam amino lengkap. Menurut Aslamsyah dan Muhammad (2013), bahwa komposisi gizi cacing tanah, yaitu protein kasar 60-72\%, lemak 7-10\%, abu 8-10\%, dan energi 900-1400 kalori/g. Menurut Astuti (2015), bahwa kadar air cacing tanah yaitu $85 \%$ dari berat tubuhnya. Menurut Julendra et al. (2010), cacing tanah mengandung zat aktif lumbricine yang bersifat anti mikroba. Menurut Lima et al. (2016), bahwa benih ikan bawal membutuhkan protein dalam pakan $31 \%$.

Penelitian yang dilakukan sebelumnya, bahwa kandungan protein yang ada pada cacing tanah sebesar $76 \%$ (Rachmawati dan Samidjan, 2015), penelitian substitusi tepung ikan dengan silase tepung cacing tanah juga sudah dilakukan pada beberapa ikan antara lain: ikan kerapu macan (Tanake et al., 2013), dan udang vanname (Rachmawati dan Samidjan, 2015). Hasil penelitian tersebut yaitu bahwa substitusi tepung ikan dengan silase cacing tanah berpengaruh nyata terhadap pertumbuhan relatif. Berdasarkan data tersebut, maka penelitian ini bertujuan untuk mengkaji pengaruh silase cacing tanah (Lumbricus sp.) sebagai substitusi tepung ikan dalam pakan buatan terhadap efisiensi pemanfaatan pakan dan pertumbuhan ikan bawal tawar (Colossoma macropomum).

\section{MATERI DAN METODE} Materi

Ikan yang digunakan dalam penelitian ini adalah benih ikan bawal air tawar (C. macropomum) berukuran 5-6,5 cm dengan rata-rata bobot awal 2,98 $\pm 0,01$ g/ekor. Ikan uji berjumlah 240 ekor yang diperoleh dari Petani Budidaya Ikan Bawal Air Tawar Ngrajek, Jawa Tengah. Padat tebar yang digunakan adalah 1 ekor/L. Pemilihan ukuran ikan bawal air tawar sebagai hewan uji penelitian ini didasarkan pada penelitian Ulviyadipura et al. (2017),

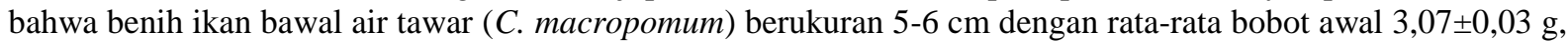
ditebar untuk tiap perlakuan dan ulangan sebanyak 1 ekor/L air. Dilakukan aklimatisasi selama 1 jam untuk mencegah ikan stres. Ikan uji dipelihara selama 7 hari supaya ikan dapat menyesuaikan diri dengan pakan dan lingkungan barunya. Kemudian, dilakukan pemuasaan selama 1 hari sebelum dilakukan pengamatan.

Pakan yang digunakan dalam penelitian ini adalah pakan buatan berbentuk pelet dengan kandungan protein $31 \%$ sesuai pernyataan Lima et al. (2016), bahwa benih ikan bawal air tawar membutuhkan protein $31 \%$. Pakan dibuat dengan perbedaan komposisi tepung ikan dengan silase cacing tanah, perlakuan A (0\%), B (25\%), C (50\%) dan D (75\%). Pemberian pakan pada ikan bawal air tawar (C.macropomum) dilakukan secara at satiation dengan frekuensi pemberian pakan sebanyak 2 kali yaitu pada pukul 08.00; dan 16.00 WIB.

Metode

Metode eksperimen yang digunakan adalah rancangan acak lengkap (RAL) dengan 4 perlakuan dan 3 kali ulangan. Perlakuan dalam penelitian ini adalah sebagai berikut: 
Perlakuan A : Substitusi $100 \%$ tepung ikan dan $0 \%$ silase cacing tanah Perlakuan B : Substitusi $75 \%$ tepung ikan dan $25 \%$ silase cacing tanah Perlakuan C : Substitusi $50 \%$ tepung ikan dan $50 \%$ silase cacing tanah Perlakuan D : Substitusi $25 \%$ tepung ikan dan $75 \%$ silase cacing tanah

Komposisi bahan pakan dan analisis proksimat pakan uji yang digunakan selama 35 hari pengamatan dapat dilihat pada Tabel 1 .

Tabel 1. Komposisi bahan pakan dan analisis proksimat pakan uji (\% bobot kering)

\begin{tabular}{|c|c|c|c|c|c|}
\hline \multirow[b]{2}{*}{ No } & \multirow{2}{*}{ Bahan Penyusun Pakan } & \multicolumn{4}{|c|}{ Pakan $(g)$} \\
\hline & & $\mathrm{A}(0 \%)$ & $\mathrm{B}(25 \%)$ & $\mathrm{C}(50 \%)$ & $\mathrm{D}(75 \%)$ \\
\hline 1 & Tepung Ikan & 28,30 & 21,22 & 14,15 & 7,08 \\
\hline 2 & Silase Cacing Tanah & 0,00 & 7,08 & 14,15 & 21,22 \\
\hline 3 & Tepung Kedelai & 28,30 & 28,30 & 28,30 & 28,30 \\
\hline 4 & Tepung Jagung & 11,64 & 11,64 & 11,64 & 11,64 \\
\hline 5 & Tepung Dedak & 11,63 & 11,63 & 11,63 & 11,63 \\
\hline 6 & Tepung Terigu & 11,63 & 11,63 & 11,63 & 11,63 \\
\hline 7 & MinyakIkan & 2,60 & 2,60 & 2,60 & 2,60 \\
\hline 8 & Minyak jagung & 2,40 & 2,40 & 2,40 & 2,40 \\
\hline 9 & Vit-min mix & 2,50 & 2,50 & 2,50 & 2,50 \\
\hline 10 & $\mathrm{CMC}$ & 1,00 & 1,00 & 1,00 & 1,00 \\
\hline & TOTAL $(\%)$ & 100 & 100 & 100 & 100 \\
\hline
\end{tabular}

Hasil Analisis proksimat pakan (\%bobot kering)

\begin{tabular}{lcccc}
\hline Protein (\%) & 30,42 & 30,56 & 31,83 & 32,56 \\
BETN (\%) & 30,97 & 31,50 & 28,40 & 28.69 \\
Lemak (\%) & 8,63 & 8,78 & 9,44 & 9,32 \\
En. (kkal/g)* & 253,798 & 256,828 & 257,749 & 261,177 \\
Rasio E/P (kkal/g) ** & 8,34 & 8,40 & 8,13 & 8,02 \\
\hline
\end{tabular}

Keterangan:

* Berdasarkan perhitungan DE (digestable energy) dengan asumsi untuk $1 \mathrm{~g}$ protein adalah 3,5 kkal/g, $1 \mathrm{~g}$ lemak adalah 8,1 kkal/g, dan $1 \mathrm{~g}$ karbohidrat adalah 2,5 kkal/g.

** Menurut De Silva (1987), nilai E/P bagi pertumbuhan optimal ikan berkisar antara 8-12 kkal/g.

Sumber: $\quad$ Laboratorium Ilmu Nutrisi dan Pakan, Fakultas Peternakan dan Pertanian, Universitas Diponegoro, Semarang (2018).

\section{Pengumpulan data}

Variabel yang diukur meliputi nilai total konsumsi pakan (TKP), efisiensi pemanfaatan pakan (EPP), FCR (rasio konversi pakan), protein efisiensi rasio (PER), laju pertumbuhan relatif (RGR), dan kelulushidupan (SR).

\section{Total konsumsi pakan} berikut:

Menurut Pereira et al. (2007), total konsumsi pakan (TKP) dihitung dengan menggunakan rumus sebagai

Keterangan:

$$
\mathrm{TKP}=\mathrm{F} 1-\mathrm{F} 2
$$

$$
\begin{aligned}
& \text { TKP }=\text { Total konsumsi pakan }(\mathrm{g}) \\
& \mathrm{F} 1=\operatorname{Jumlah} \text { pakan awal }(\mathrm{g}) \\
& \mathrm{F} 2=\operatorname{Jumlah} \text { pakan akhir }(\mathrm{g})
\end{aligned}
$$

\section{Efisiensi pemanfaatan pakan}

Menurut Zonneveld et al. (1991), nilai efisiensi pemanfaatan pakan (EPP) dihitung berdasarkan rumus sebagai berikut:

Keterangan:

$$
\mathrm{EPP}=\frac{\mathrm{W}_{\mathrm{t}}-\mathrm{W}_{\mathrm{o}}}{\mathrm{F}} \times 100 \%
$$

$$
\begin{aligned}
& \mathrm{EPP}=\text { Efisiensi pemanfaatan pakan }(\%) \\
& \mathrm{W}_{\mathrm{t}}=\text { Bobot total ikan pada akhir penelitian }(\mathrm{g}) \\
& \mathrm{W}_{\mathrm{o}}=\text { Bobot total ikan pada awal penelitian }(\mathrm{g}) \\
& \mathrm{F}
\end{aligned}
$$




\section{Rasio Konversi Pakan} berikut:

Menurut Sammouth et al. (2009), nilai rasio konversi pakan (FCR) dapat dihitung menggunakan sebagai

$$
\text { FCR }=\text { F/(Bf-Bi })
$$

Keterangan:

$$
\begin{array}{ll}
\mathrm{FCR} & =\text { Feed Convertion Ratio } \\
\mathrm{F} & =\text { Berat total pakan yang diberikan }(\mathrm{g}) \\
\mathrm{B}_{\mathrm{f}} & =\text { Biomassa akhir ikan }(\mathrm{g}) \\
\mathrm{B}_{\mathrm{i}} & =\text { Biomassa awal ikan }(\mathrm{g})
\end{array}
$$

\section{Protein efisiensi rasio}

Menurut Zonneveld et al. (1991), nilai protein efisiensi rasio (PER) dihitung berdasarkan rumus sebagai berikut:

$$
\mathrm{PER}=\frac{\mathrm{W}_{\mathrm{t}}-\mathrm{W}_{\mathrm{o}}}{\mathrm{Pi}} \times 100 \%
$$

Keterangan:

$$
\begin{aligned}
& \mathrm{PER}=\text { Protein efisiensi rasio }(\%) \\
& \mathrm{W}_{\mathrm{t}}=\text { Bobot total ikan pada akhir penelitian }(\mathrm{g}) \\
& \mathrm{W}_{\mathrm{o}}=\text { Bobot total ikan pada awal penelitian }(\mathrm{g}) \\
& \mathrm{Pi}=\text { Berat pakan yang dikonsumsi } \mathrm{x} \% \text { protein pakan }
\end{aligned}
$$

\section{Laju pertumbuhan relatif} berikut:

Menurut Takeuchi, (1988) Laju pertumbuhan relatif (RGR) ikan dihitung berdasarkan rumus sebagai

$$
\mathrm{RGR}=\frac{\mathrm{W}_{\mathrm{t}}-\mathrm{W}_{\mathrm{o}}}{\mathrm{W}_{\mathrm{n}} \times \mathrm{t}} \times 100 \%
$$

Keterangan :

$\mathrm{RGR}=$ Laju pertumbuhan relatif $(\%$ per hari $)$

$\mathrm{W}_{\mathrm{t}} \quad$ = Bobot total ikan pada akhir pemeliharaan $(\mathrm{g})$

$\mathrm{W}_{\mathrm{o}} \quad=$ Bobot total ikan pada awal pemeliharaan $(\mathrm{g})$

$\mathrm{t} \quad=$ Waktu pemeliharaan (hari)

\section{Kelulushidupan}

Menurut Zonneveld et al. (1991) kelulushidupan dapat dihitung berdasarkan rumus sebagai berikut:

$$
\mathrm{SR}=\frac{\mathrm{Nt}}{\mathrm{N}_{\mathrm{o}}} \times 100 \%
$$

Keterangan:

$$
\begin{aligned}
& \mathrm{SR}=\text { Tingkat kelulushidupan ikan (\%) } \\
& \mathrm{N}_{\mathrm{t}} \text { = Jumlah ikan pada akhir penelitian (ekor) } \\
& \mathrm{N}_{0}=\text { Jumlah ikan padaawal penelitian (ekor) }
\end{aligned}
$$

\section{Kualitas air}

Pengelolaan kualitas air pada media pemeliharaan dilakukan dengan mengukur parameter kualitas air meliputi suhu, oksigen terlarut (DO), derajat keasaman $(\mathrm{pH})$, dan amonia $\left(\mathrm{NH}_{3}\right)$. Pengamatan suhu dilakukan setiap hari pada waktu pagi dan sore, sedangkan DO dilakukan satu minggu sekali pada waktu pagi dan sore menggunakan water quality cheker, dengan cara mencelupkan ujung alat indikator (probe) ke dalam air kemudian menunggu hingga konstan dan mencatat nilainya. Pengukuran $\mathrm{pH}$ dilakukan satu minggu sekali pada waktu pagi dan sore dengan menggunakan $\mathrm{pH}$ meter dengan cara mencelupkan $\mathrm{pH}$ meter pada wadah pemeliharaan dan melihat hasilnya. Pengamatan kualitas air amonia dilakukan pada awal dan akhir yang dianalisis di Laboratorium Departemen Teknik Lingkungan Universitas Diponegoro. Penambahan aerasi dilakukan sebagai upaya untuk menambah oksigen terlarut selama masa pemeliharaan. Penyiponan dilakukan setiap hari agar kotoran yang mengendap di dasar wadah tidak menumpuk, sehingga kualitas air tetap terjaga.

\section{Analisis data}

Data yang diperoleh meliputi TKP, EPP, FCR, PER, RGR, dan SR, terlebih dahulu dilakukan uji normalitas, uji homogenitas, dan uji additivitas guna memastikan bahwa data bersifat normal, homogen, dan aditif. Data kemudian dilakukan uji lebih lanjut yaitu analisis ragam (ANOVA). Analisis data dilakukan dengan menggunakan Microsoft Excel 2016 dan SPSS versi 25.0. Data dianalisis ragam (uji F) pada taraf kepercayaan 
95\%. Apabila dalam analisis ragam diperoleh beda nyata $(\mathrm{P}<0,05)$, maka dilakukan uji wilayah ganda Duncan untuk mengetahui perbedaan nilai tengah antara perlakuan. Data kualitas air dianalisis secara deskriptif dan dibandingkan dengan nilai kelayakan kualitas air pada budidaya ikan bawal air tawar.

\section{HASIL}

Hasil pengukuran rerata nilai total konsumsi pakan (TKP), efisiensi pemanfaatan pakan (EPP), rasio konversi pakan (FCR), protein efisiensi rasio (PER), laju pertumbuhan relatif (RGR), dan kelulushidupan (SR) tersaji dalam Tabel 2.

Tabel 2. Nilai rerata TKP, EPP, FCR, PER, RGR, dan SR pada ikan bawal air tawar (C. macropomum) selama 35 hari pengamatan.

\begin{tabular}{ccccccc}
\hline \multirow{2}{*}{ Perlakuan } & \multicolumn{7}{c}{ Variabel yang diamati } \\
\cline { 2 - 6 } & TKP $(\mathrm{g})$ & EPP $(\%)$ & FCR & PER (\%) & RGR (\%/hari) & SR (\%) \\
\hline A & $136,43^{\mathrm{b}} \pm 2,61$ & $51,18^{\mathrm{c}} \pm 2,76$ & $1,96^{\mathrm{c}} \pm 0,10$ & $1,68^{\mathrm{c}} \pm 0,09$ & $3,34^{\mathrm{c}} \pm 0,23$ & $85,00^{\mathrm{a}} \pm 4,08$ \\
B & $142,67^{\mathrm{a}} \pm 3,06$ & $61,98^{\mathrm{b}} \pm 3,21$ & $1,62^{\mathrm{b}} \pm 0,09$ & $2,03^{\mathrm{b}} \pm 0,11$ & $4,26^{\mathrm{b}} \pm 0,27$ & $85,00^{\mathrm{a}} \pm 5,00$ \\
C & $145,13^{\mathrm{a}} \pm 2,90$ & $75,11^{\mathrm{a}} \pm 3,36$ & $1,33^{\mathrm{a}} \pm 0,06$ & $2,36^{\mathrm{a}} \pm 0,11$ & $5,22^{\mathrm{a}} \pm 0,36$ & $90,00^{\mathrm{a}} \pm 5,00$ \\
D & $145,03^{\mathrm{a}} \pm 3,33$ & $66,13^{\mathrm{b}} \pm 2,71$ & $1,51^{\mathrm{b}} \pm 0,06$ & $2,03^{\mathrm{b}} \pm 0,08$ & $4,62^{\mathrm{b}} \pm 0,28$ & $90,00^{\mathrm{a}} \pm 5,00$ \\
\hline
\end{tabular}

Keterangan: Nilai variabel dengan huruf superscript yang berbeda menunjukkan hasil yang berbeda nyata $(\mathrm{P}<0,05)$

Berdasarkan rata-rata nilai total konsumsi pakan (TKP) pada masing-masing perlakuan dari yang tertinggi hingga terendah adalah perlakuan C $145,13 \pm 2,90$ gram, perlakuan D sebesar $145,03 \pm 3,33$ gram, perlakuan B

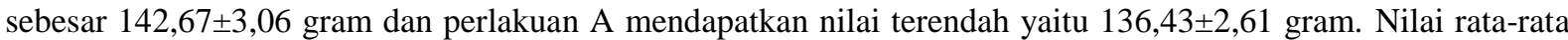
efisiensi pemanfaatan pakan (EPP) pada masing-masing perlakuan dari yang tertinggi hingga terendah adalah perlakuan C sebesar 75,11 $\pm 3,36 \%$, perlakuan D sebesar $66,13 \pm 2,71 \%$, perlakuan B sebesar $61,98 \pm 3,21 \%$ dan perlakuan A mendapatkan nilai terendah yaitu 51,18 $\pm 2,76 \%$. Nilai rata-rata rasio konversi pakan (FCR) pada masing-masing perlakuan dari yang tertinggi hingga terendah adalah nilai tertinggi pada perlakuan A sebesar $1,96 \pm 0,10$, perlakuan B sebesar 1,62 $\pm 0,09$, perlakuan D sebesar 1,51 $\pm 0,06$ dan perlakuan C mendapatkan nilai terendah yaitu $1,33 \pm 0,06$. Nilai rata-rata rasio efisiensi protein (PER) pada masing-masing perlakuan dari yang tertinggi hingga terendah adalah perlakuan C sebesar 2,36 $\pm 0,11 \%$, perlakuan D sebesar 2,03 $\pm 0,08 \%$, perlakuan B sebesar 2,03 $\pm 0,11 \%$ dan perlakuan A mendapatkan nilai terendah yaitu $1,68 \pm 0,09 \%$. Nilai rata-rata laju pertumbuhan relative (RGR) pada masing-masing perlakuan dari yang tertinggi hingga terendah adalah perlakuan C sebesar 5,22 $\pm 0,35 \%$ /hari, perlakuan D sebesar 4,62 $\pm 0,28 \%$ /hari, perlakuan B sebesar 4,26 $\pm 0,27 \% /$ hari dan

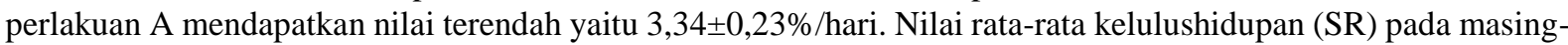
masing perlakuan dari yang tertinggi hingga terendah adalah perlakuan C dan D sama yaitu sebesar 90,00 $\pm 5,00 \%$, dilanjut perlakuan B yaitu sebesar $85,00 \pm 5,00 \%$ dan perlakuan A sebesar $85,00 \pm 4,08 \%$.

\section{Kualitas Air}

Tabel 3. Hasil Pengukuran Parameter Kualitas Air pada Media Budidaya Ikan Bawal Air Tawar (C. macropomum) selama Penelitian.

\begin{tabular}{ccccc}
\hline \multirow{2}{*}{ Perlakuan } & \multicolumn{4}{c}{ Kisaran Nilai Parameter Kualitas Air } \\
\cline { 2 - 5 } & Suhu $\left({ }^{\mathbf{0}} \mathbf{C}\right)$ & $\mathbf{p H}$ & $\mathbf{D O}(\mathbf{m g} / \mathbf{l})$ & NH3 $(\mathbf{m g} / \mathbf{l})$ \\
\hline A & $24,6-29,0$ & 7 & $4,47-4,82$ & $0,0016-0,0068$ \\
B & $24,1-29,0$ & 7 & $4,51-4,77$ & $0,0014-0,0085$ \\
C & $24,5-28,8$ & 7 & $4,64-4,76$ & $0,0020-0,0081$ \\
D & $24,7-28,8$ & 7 & $4,66-4,81$ & $0,0031-0,0114$ \\
\hline Kelayakan & $25-30^{\mathrm{a}}$ & $6-8^{\mathrm{b}}$ & $\geq 3^{\mathrm{c}}$ & $<1^{\mathrm{a}}$ \\
\hline
\end{tabular}

Keterangan:a) Khalida et al.,(2017); b)Santoso dan Agusmansyah(2011); dan c) Zonneveld (1991)

\section{PEMBAHASAN}

Berdasarkan hasil penelitian yang telah dilakukan, silase cacing tanah sebagai substitusi tepung ikan terbukti berpengaruh nyata $(\mathrm{P}<0,05)$ terhadap total konsumsi pakan $(\mathrm{TKP})$, efisiensi pemanfaatan pakan $(\mathrm{EPP})$, rasio konversi pakan (FCR), protein efisiensi rasio (PER) dan pertumbuhan ikan bawal air tawar (C. macropomum) tetapi tidak berpengaruh nyata $(\mathrm{P}>0,05)$ terhadap kelulushidupan ikan bawal air tawar.

\section{Pemanfaatan Pakan}

Berdasarkan hasil mengenai tingkat konsumsi pakan menunjukan bahwa nilai tingkat konsumsi pakan (TKP) dengan penambahan silase cacing tanah dalam pakan uji diduga mempengaruhi palatabilitas pakan di bandingkan dengan perlakuan A (0\% silase cacing tanah). Menurut Pamungkas (2013), bahwa jumlah konsumsi pakan merupakan salah satu indikator untuk menentukan tingkat palatabilitas pakan yang diberikan. Faktor-faktor yang mempengaruhi konsumsi pakan antara lain kandungan nutrisi, palatabilitas, suhu, umur, bobot badan dan 
kapasitas lambung. Palatabilitas pakan ditentukan oleh bentuk, ukuran, rasa, bau, aroma dan warna yang merupakan faktor fisik dan kimia pakan.

Efisiensi pemanfaatan pakan silase cacing tanah sebagai substitusi tepung ikan secara berturut-turut pada perlakuan A sampai perlakuan C mengalami kenaikan namun pada perlakuan $\mathrm{C}$ ke perlakuan $\mathrm{D}$ mengalami penurunan, hal tersebut di duga bahwa semakin banyak silase cacing tanah yang di tambahkan pada pakan uji D, pakan sulit di cerna ikan bawal air tawar secara efisien, karena pada tubuh cacing tanah terdapat rambut kaku yang terbuat dari zat kitin. Menurut Nilawati et al. (2014), cacing tanah dikelompokkan dalam ordo oligochaeta merupakan annelida yang memiliki sedikit rambut kaku pada tiap segmen tubuh. Zat kitin merupakan bahan yang tidak bisa dicerna oleh ikan (Budiutami et al., 2012). Sehingga semakin banyak penambahan silase cacing tanah pada pakan uji perlakuan D, menyebabkan efisiensi pemanfaatan pakan, protein efisiensi protein dan rasio konversi pakan turun. Kitin adalah polimer glukosamin dan tidak larut dalam air. Berbagai peneliti melaporkan bahwa kitin ini dapat menurunkan pertumbuhan ikan (Beg et al.,2016).

Berdasarkan hasil mengenai rasio konversi pakan menunjukan bahwa nilai rasio konversi pakan (FCR) silase cacing tanah sebagai substitusi tepung ikan nilai tertinggi ke terendah yaitu perlakuan A sebesar 1,96 $\pm 0,10$, di ikuti dengan perlakuan B sebesar 1,62 $\pm 0,09$, dan selanjutnya perlakuan D sebesar 1,51 $\pm 0,06$ dan perlakuan C

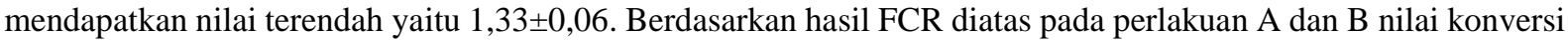
pakan tinggi, namun pada perlakuan $\mathrm{C}$ konversi pakan semakin rendah, tetapi pada perlakuan $\mathrm{D}$ nilai konversi pakan cenderung naik, hal tersebut di duga bahwa pakan pada perlakuan $\mathrm{C}$ (50\% silase cacing tanah) dapat di cerna oleh ikan bawal secara efisien, ditunjukkan dengan perlakuan C nilai EPP tinggi. Menurut Putri et al. (2012), nilai konversi pakan berhubungan erat dengan kualitas pakan, sehingga semakin rendah nilainya maka semakin baik kualitas pakan dan efisien ikan dalam memanfaatkan pakan yang dikonsumsinya untuk pertumbuhan. Tingginya nilai konversi pakan pada perlakuan A diduga kurangnya kemampuan ikan dalam menyerap nutrisi pada pakan tersebut. Menurut Ardita et al. (2015), konversi pakan dipengaruhi oleh daya serap nutrisi pakan oleh saluran percernaan ikan.

Berdasarkan nilai rasio konversi pakan (FCR) untuk ikan bawal air tawar, perlakuan terbaik dalam penelitian ini yaitu terdapat pada perlakuan C (50\% silase cacing tanah) sebesar 1,33 $\pm 0,06$, nilai ini lebih kecil dari penelitian Tanake et al. (2013), bahwa nilai rasio konversi (FCR) pakan untuk ikan kerapu macan dengan substitsi tepung ikan dengan silase tepung cacing tanah pada perlakuan C (50\% silase cacing tanah) nilai FCR 3,22 $\pm 0,32$, sedangkan pada penelitian Rachmawati dan Samidjan (2015), bahwa nilai FCR pada udang vannamei dengan substitusi tepung ikan dengan silase tepung cacing tanah dalam pakan buatan pada perlakuan C (50\% silase cacing tanah) nilai FCR 3,631 $\pm 0,211$. Perbedaan nilai FCR antar penelitian tersebut di duga karena adanya perbedaan kemampuan ikan dalam menyerap nutrisi pakan yang di berikan. Menurut Bulbul et al. (2013), perbedaan yang dihasilkan oleh tingkat konversi pakan dapat disebakan oleh penyerapan nutrisi dan mineral setiap spesies, umur dan ukuran ikan yang berbeda-beda. Widyasunu et al. (2013), menambahkan kecernaan pakan dipengaruhi oleh faktor fisika kimia makanan, jenis makanan, kandungan gizi makanan, jumlah enzim pencernaan pada sistem pencernaan ikan, ukuran ikan, serta sifat fisik dan kimia perairan.

Berdasarkan hasil penelitian protein efisiensi rasio (PER) antar perlakuan dari tertinggi sampai terendah yaitu perlakuan $\mathrm{C}$ sebesar 2,36 $\pm 0,11 \%$, diikuti dengan perlakuan D sebesar 2,03 $\pm 0,08 \%$, kemudian dilanjut dengan perlakuan B sebesar 2,03 $\pm 0,11 \%$ dan perlakuan A mendapatkan nilai terendah yaitu 1,96 $\pm 0,10 \%$. Nilai PER pada perlakuan A sampai perlakuan C mengalami kenaikan tapi pada perlakuan D (75\% silase cacing tanah) terjadi penurunan, hal tersebut di duga bahwa pada pakan D pemanfaatan protein kurang efisien karena pakan D penambahan silase cacing tanah paling banyak dibandingkan dengan pakan perlakuan B dan C, sehingga pakan D banyak terdapat zat kitin di tandai juga nilai EPP pada perlakuan D juga mengalami penurunan. Menurut Beg et al. (2016), kitin dapat menghambat penyerapan nutrisi dari saluran usus sehingga proses pemanfaatan pakan dan pemanfaatan protein juga akan terganggu sehingga pertumbuhan akan menurun, selain itu kandungan protein pada pakan D juga melebihi kebutuhan ikan bawal air tawar, oleh karena itu ikan kurang dapat mencerna pakan yang diberikan sehingga protein akan di katabolisme menjadi amonia dan energi dalam pakan meningkat. Menurut Adelia et al.(2000), bahwa kelebihan protein yang tidak digunakan dalam sintesis protein akan di katabolisme yang akhirnya di ekskresikan berupa amonia. Semakin banyak protein yang dikatabolisme maka akan meningkatkan energi untuk mengoksidasi kelebihan asam amino yang akhirnya akan meningkatkan amonia yang diproduksi. Subandiyono dan Hastuti (2011), menambahkan bahwa setelah energi yang digunakan untuk pemeliharaan tubuh, metabolisme basal, dan aktivitas, sisanya akan digunakan untuk pertumbuhan. Imbangan kandungan protein dan energi dalam pakan menjadi penting untuk diperhatikan karena kekurangan atau kelebihan energi dalam pakan dapat menurunkan tingkat pertumbuhan. Bilamana energi dalam pakan kurang, maka protein digunakan sebagai energi. Bilamana energi dalam pakan berlebih, maka konsumsi pakan akan menurun dan hal tersebut menurunkan pengambilan sejumlah protein yang diperlukan utuk pertumbuhan. Protein pakan pada perbandingan optimum terhadap energi (optimum protein to energi ratio) dapat menghasilkan pertumbuhan yang baik. Hal tersebut dikarenakan protein pakan adalah juga sumber energi pakan dan energi pakan diperlukan dalam pembentukan protein tubuh. Pembentukan protein tubuh pada akhirnya merupakan bagian dari energi cadangan dari hewan tersebut. 
Nilai protein efisiensi rasio (PER) tertinggi antar perlakuan dalam penelitian ini yaitu terdapat pada perlakuan C (50\% silase cacing tanah) sebesar 2,36 $\pm 0,11 \%$, di duga bahwa protein dalam pakan pada penelitian ini mampu terurai menjadi asam amino dan penyusunya, sehingga protein dalam pakan tersebut mudah diserap oleh tubuh ikan. Menurut Rachmawati, (2013) semakin tinggi nilai PER berarti pakan itu lebih efisien dan protein dapat dimanfaatkan secara maksimal. Sedangkan rendahnya nilai protein efisiensi rasio (PER) pada perlakuan A (0\% silase cacing tanah) diduga bahwa pada pakan uji A memilki komponen asam amino lebih rendah dibandingkan dengan pakan perlakuan B, C dan D yang di tambahkan silase cacing tanah. Menurut Hayati et al. (2011), bahwa komposisi asam amino essensial tepung cacing tanah umumnya lebih tinggi dibandingkan dengan tepung ikan. Tepung cacing tanah mengandung fenilalanin 1,77; valin 5,12; methionin 3,64; isoleusin 4,20; threonin 2,29; histidin 5,76; arginin 3,01; lisin 8,69; leusin 4,64; sistin 2,51. Menurut Curiel et al. (2016), bahwa tepung ikan mengandung fenilalanin 2,50; valin 2,30; methionin 2,30; isoleusin 2,20; threonin 2,80; histidin 1,80; arginin 3,80; lisin 4,20; leusin 4,40. Sedangkan Menurut Zhao et al. (2010), kebutuhan asam amino ikan bawal air tawar yaitu lisin 8,27 ; leusin 7,66; isoleusin 4,42; fenilalanin 3,85; tirosin 3,91; valin 5,15; sistin 1,20; methionine 1,13; histidin 1,66; dan threonine 4,02.

\section{Laju pertumbuhan relatif (RGR)}

Berdasarkan hasil analisis ragam silase cacing tanah sebagai substitusi tepung ikan $(0 \%, 25 \%, 50 \%$ dan $75 \%$ ) pada pakan buatan memberikan pengaruh yang nyata terhadap laju pertumbuhan relatif (RGR). Hasil uji Duncan laju pertumbuhan relatif pada ikan bawal air tawar (C. macropromum) menunjukkan bahwa perlakuan $\mathrm{C}$ berbeda nyata dengan perlakuan $\mathrm{D}, \mathrm{B}$ dan $\mathrm{A}(\mathrm{P}<0,05)$. Perlakuan $\mathrm{D}$ tidak berbeda nyata dengan perlakuan $\mathrm{B}$ $(\mathrm{P}<0,05)$, namun berbeda nyata dengan perlakuan $\mathrm{A}$, dan $\mathrm{C}(\mathrm{P}<0,05)$. Perlakuan $\mathrm{B}$ berbeda nyata dengan perlakuan A dan $\mathrm{D}$, namun tidak berbeda nyata dengan perlauan $\mathrm{D}(\mathrm{P}>0,05)$. Perlakuan A berbeda nyata dengan perlakuan $\mathrm{A}, \mathrm{B}$ dan $\mathrm{D}(\mathrm{P}<0,05)$. Nilai laju pertumbuhan relatif antar perlakuan dari tertinggi sampai terendah yaitu perlakuan

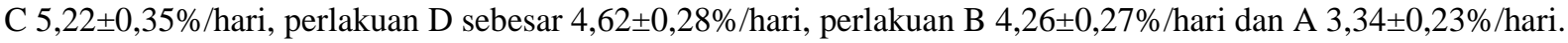
Nilai RGR pada perlakuan A sampai perlakuan C selalu meningkat, namun pada perlakuan C ke D menurun, hal tersebut di duga bahwa pakan D memiliki kandungan protein lebih tinggi di bandingkan pakan C. Meskipun nilai kandungan protein dalam pakan tinggi, namun pertumbuhannya rendah hal ini dikarenakan kualitas protein pakan tersebut tidak sesuai dengan kebutuhan ikan bawal air tawar. Menurut Abidin et al. (2015), bahwa kualitas pakan tidak hanya ditentukan oleh tingginya kandungan gizi namun juga ditentukan oleh kemampuan ikan mencerna dan menyerap pakan yang dimakan.

Berdasarkan nilai laju pertumbuhan relatif (RGR) ikan bawal air tawar, perlakuan C (50\% silase cacing tanah) memperoleh nilai laju pertumbuhan tertinggi yaitu sebesar 5,22 $\pm 0,35 \%$ /hari dibandingkan perlakuan yang lain. Tingginya nilai laju pertumbuhan pada perlakuan $\mathrm{C}$, di duga bahwa pada pakan uji $\mathrm{C}$ memiliki komposisi pakan yang sesuai atau mirip dengan tubuh ikan bawal air tawar dibuktikan dengan hasil uji proksimat pakan, sehingga pakan banyak diserap dan digunakan untuk pertumbuhan daripada untuk metabolisme. Tingginya nilai RGR pada perlakuan C didukung dengan tingginya nilai efisiensi pemanfaatan pakan (EPP), protein efisiensi rasio (PER) pada perlakuan C juga tinggi dan nilai rasio konversi pakan (FCR) rendah. Menurut Khalida et al. (2017), bahwa pakan yang mengandung komposisi nutrisi terutama protein sesuai dengan kebutuhan ikan bawal air tawar, mampu diserap oleh tubuh secara optimal untuk pertumbuhan. Ketersediaan asam amino pakan untuk disimpan menjadi asam amino tubuh atau protein tubuh semakin besar dengan penambahan protein dalam pakan. Penggunaan pakan dengan kandungan protein yang sesuai kebutuhan dan jumlah optimum akan menyebabkan pembentukan jaringan baru sehingga laju pertumbuhan meningkat. Laju pertumbuhan yang tinggi berkaitan dengan efisiensi pakan yang tinggi juga. .Helper dalam Rachmawati dan Istiyanto (2015), menambahkan pakan yang baik untuk pertumbuhan adalah pakan yang mempunyai pola asam amino yang hampir sama atau mirip dengan pola asam amino tubuh ikan. Jika asupan protein dalam pakan sesuai tubuh ikan maka banyak di serap untuk pertumbuhan dan memperbaiki sel-sel yang sudah rusak dan kelebihannya di ekskresikan dalam bentuk amonia.

\section{Kelulushidupan}

Berdasarkan hasil analisa ragam menunjukkan bahwa silase cacing tanah sebagai substitusi tepung ikan dalam pakan buatan menunjukkan pengaruh yang tidak nyata $(\mathrm{P}>0,05)$ terhadap kelulushidupan ikan bawal air tawar (C. macropomum), hal tersebut diduga bahwa pakan dengan penggantian tepung ikan dengan silase tepung cacing tanah pada pakan buatan memberikan pengaruh pada pertumbuhan, akan tetapi tidak memberikan pengaruh nyata terhadap tingkat kelulushidupan. Tingkat kelulushidupan ikan bawal air tawar pada penelitian ini tergolong baik yaitu 85,00-90,00\%. Tingginya nilai kelulushidupan ikan bawal air tawar yang diperoleh dalam penelitian ini diduga parameter kualitas air selama pemeliharaan masih berada dalam batas kondisi optimum untuk keperluan budidaya sehingga layak bagi kelulushidupan ikan bawal air tawar. Menurut Kelaborah dan Subariah (2010), kelangsungan hidup ikan bawal air tawar dipengaruhi secara langsung oleh kualitas air. Kualitas air yang memenuhi syarat dapat membuat pertumbuhan dan kelangsungan ikan menjadi baik. Faktor-faktor yang mempengaruhi tinggi rendahnya persentase kelulushidupan adalah faktor abiotik seperti faktor fisika dan kimia lingkungan perairan serta faktor biotik seperti kompetitor, parasit dan kemampuan beradaptasi dengan lingkungan. 


\section{KESIMPULAN DAN SARAN \\ Kesimpulan}

Kesimpulan yang didapat dari penelitian ini bahwa:

1. Penggunaan silase cacing tanah sebagai substitusi tepung ikan pada pakan buatan yang diberikan pada ikan bawal air tawar (C. macropomum) memberikan pengaruh yang nyata terhadap total konsumsi pakan (TKP) efisiensi pemanfaatan pakan (EPP), rasio konversi pakan (FCR), rasio efisiensi protein (PER) dan laju pertumbuhan relatif (RGR) namun tidak memberikan pengaruh yang nyata terhadap dan kelulushidupan (SR);

2. Komposisi terbaik silase cacing tanah sebagai substitusi tepung ikan yang diberikan pada ikan bawal air tawar (C. macropomum) yaitu perlakuan C (50\% tepung ikan dan 50\% silase cacing tanah) dalam pakan buatan yang memberikan nilai TKP, EPP, FCR, PER dan RGR dengan masing-masing 145,13 $\pm 2,90$ gram, $75,11 \pm 3,36 \%, 1,33 \pm 0,06,2,36 \pm 0,11 \%$, dan $5,22 \pm 0,36 \%$ /hari.

Saran

Saran yang dapat diberikan pada penelitian ini adalah penggunaan silase cacing tanah sebagai substitusi tepung ikan dengan komposisi 50\% tepung ikan dan 50\% silase cacing tanah dalam pakan buatan dapat meningkatkan pemanfaatan pakan dan pertumbuhan pada benih ikan bawal air tawar.

\section{Ucapan Terimakasih}

Terimakasih penulis ucapkan kepada Bapak Taufiq selaku kepala Balai Benih Ikan (BBI) Siwarak yang telah memberikan fasilitas selama penelitian, serta semua pihak yang telah membantu selama penelitian di lapangan, sehingga penulis dapat menyelesaikan penelitian ini.

\section{DAFTAR PUSTAKA}

Abidin, Z., M. Junaidi, Paryono, N. Cokrowati dan S. Yuniarti. 2015. Pertumbuhan dan Konsumsi Pakan Ikan Lele yang Diberi Pakan Berbahan Baku Lokal., J. Depik. 4(1): 33-39.

Adelia., Mokoginta, I.,Ridwan, A.,dan Dedi Jusadi. 2000. Pengaruh Kadar Protein dan Rasio Energi Protein Pakan Berbeda Terhadap Kinerja Pertumbuhan Benih Ikan Bawal Air Tawar (Colossoma macropomum)., J. Perikanan Indonesia.9(2): 31-36.

Ardita, N., A. Budihardjo dan S. L. A. Sari. 2015. Pertumbuhan dan Rasio Konversi Pakan Ikan Nila (O. niloticus) dengan Penambahan Prebiotik., J. Bioteknologi. 12(1): 16-21.

Aslamyah, S dan Muhammad Yusri Karim. 2013. Potensi Tepung Cacing Tanah Lumbricus Sp. Sebagai Pengganti Tepung Ikan dalam Pakan Terhadap Kinerja Pertumbuhan, Komposisi Tubuh, Kadar Glikogen Hati dan Otot Ikan Bandeng Chanos Chanos Forsskal., J. Iktiologi Indonesia. 13(1):67-76.

Astuti, R.T. 2015. Protein Cacing Tanah Sebagai Sumber Protein Alternatif dari Pengolahan Limbah Ruminansia Besar. [Skripsi]. Institut Pertanian Bogor. Bogor.

Beg, M. M., B. Mandal dan S. Moulick. 2016. Potential of Eartworm meal as a Replacement of Fish meal for Indian Major Carps. J,. of Fisheries and Aquatic Studies. 4(3): 357-361.

Budiutami, A., N. K. Sari dan S. Priyanto. 2012. Optimasi Proses Ekstraksi Kitin Menjadi Kitosan dari Limbah Kulit Ulat Hongkong (Tenebrio molitor). J., Teknologi Kimia dan Industri. 1(1): 46-53

Bulbul, M., Md. A. Kader, M. A. AMbak, Md. S. Hossain, M.Ishikawa dan S. Koshio. 2013. Effects of Crystalline Amino Acid, Phytase and Fish Soluble Suplements in Improving Nutritive Value of Hight Plant Protein based Diets for Kuruma Shrimp, Marsepaenus japonicas. Aquaculture Elsevier., 438: 98-104.

Curiel, F,B. Griselda, P.S dan Gabriel Correa Reyes. 2016. Total and Partial Fishmeal Substitution by Poultry by Product Meal (Petfood Grade) and Enrichment With Acid Fish Silage in Aquafeeds For Juveniles of Rainbow Trout (Oncohynchus mykiss)., J. Aquatic Research. 44(2): 327 - 335.

De Silva, S. S., T. A. Anderson. 1987. Fish Nutrition in Aquaculture. Chapman and Hall. 2-6 Boundary Row, London. 319 p.

Hayati, S.N., Herdian H, Damayanti E, Istiqomah L, Julendra H. 2011. Profil Asam Amino Ekstrak Cacing Tanah (Lumbricus rubellus) Terenkapsulasi dengan Metode Spraydrying., J. Teknologi Indonesia., 3(4):1-7.

Julendra, H., Zuprizal dan Supadmo. 2010. Penggunaan Tepung Cacing Tanah (Lumbricus rubellus) sebagai Aditif Pakan Terhadap Penampilan Produksi Ayam Pedaging, Profil Darah, dan Kecernaan Protein. Buletin Peternakan., 34(1):21-26.

Kardana, D., K. Haetami dan U. Subhan. 2012. Efektivitas Penambahan Tepung Maggot dalam Pakan Komersial Terhadap Pertumbuhan Benih Ikan Bawal Air Tawar (Colossoma macropomum)., J. Perikanan dan Kelautan. 3(4): 177-184.

Khalida, A., Agustono dan W. Paramita . 2017. Penambahan Lisin Pada Pakan Komersial Terhadap Retensi Protein dan Retensi Energi Ikan Bawal Air Tawar (Colossoma macropomum)., J. Ilmiah Perikanan dan Kelautan.9(2)., 98-106.

Lima, C.D.S., Marcos, A.D.B., Jefferson, C.S., Felipf, B.R., dan Eduardo Arruda Teixeira Lanna. 2016. Crude Protein Levels in the Diets of Tambaqui, Colossoma macropomum (Cuvier, 1818), Fingerlings., Universidade Federal Rural do SemiÁrido., 183 - 190. 
Nilawati, S., Dahelmi dan J. Nurdin. 2014. Jenis-Jenis Cacing Tanah (Oligochaeta) yang Terdapat di Kawasan Cagar Alam Lembah Anai Sumatera Barat. J., Biologi Univeritas Andalas. 3(2): 87-91

Pamungkas, W. 2013. Uji Palatabilitas Tepung Bungkil Kelapa Sawit yang Dihidrolisis dengan Enzim Rumen dan Efek Terhadap Respon Pertumbuhan Benih Ikan Patin Siam (Pangasius Hypophthalmus Sauvage)., J. Berita Biologi.,12(3): 359 - 366.

Pereira, E. M., F. A. P. Santos, C. M. M. Bittar, T. R. Ramalho, D. F. A. Costa, and J. C. Martinez. 2007. Substitution of Corn Grain by Wheat Middlings or Corn Gluten Feed in The Finishing Bulls Diet. Acta Scientiarum - Animal Sciences. 29(1): 49-55.

Putri, S. F., Z. Hasan dan K. Haetami. 2012. Pengaruh Pemberian Bakteri Probiotik Pada Pelet yang Mengandung Kaliandra (Calliandra calothyrus) Terhadap Pertumbuhan Benih Ikan Nila (O. niloticus)., J. Perikanan dan Kelautan. 3(4): 283-291.

Rachmawati, D. 2013. Performa Laju Pertumbuhan Relatif dan Kelulushidupan Kerapu Macan (Epinephelus fuscoguttatus) melalui Substitusi Tepung Ikan dengan Tepung Cacing Tanah (Lumbricus rubellus) dalam Pakan Buatan. Buletin Oseanografi Marina. 2(4): 9-17.

dan I. Samidjan. 2015. Performan Laju Pertumbuhan Relatif dan Kelulushidupan Udang Vanname (Litopenaeus vannamei) Melalui Substitusi Tepung Ikan dengan Silase Tepung Cacing Tanah (Lumbricus rubellus) : 72-86.

Sammouth S., d'Orbcastel ER., Gasset E, Lemarie G, Breuil G, Marino G, Coeurdacier JL., Fivelstad S and Blancheton JP. 2009. The effect of density on Sea Bass (Dicentrarchus labrax) Performance in a Tank Based Recirculating System. Aquac Eng., 40: 72 - 78.

Santoso, L., dan H. Agusmansyah. 2011. Pengaruh Substitusi Tepung Kedelai dengan Tepung Biji Karet pada Pakan Buatan Terhadap Pertumbuhan Bawal Air Tawar (Colossoma macropomum)., J., Berkala Perikanan Terubuk. 39(1): 41-50.

Subandiyono dan S. Hastuti. 2011. Buku Ajar Nutrisi Ikan. Lembaga Pengembangan dan Penjaminan Mutu Pendidikan. Universitas Diponegoro. Semarang, $182 \mathrm{hlm}$

Takeuchi, T., S. Sadoh dan V. Kiron. 2002. Nutrient Requierement and Feeding on Finfish Aquaculture:245-261.

Tanake, G.L. Diana Rachmawati dan Subandiyono. 2013. Pengaruh Substitusi Tepung Ikan dengan Silase Cacing Tanah (Lumbricus rubellus) dalam Pakan Buatan Terhadap Pemanfaatan Pakan dan Pertumbuhan Juvenil Kerapu Macan (Epinephelus fuscogutattus)., J. of Aquaculture Management And Technology. 2(3): 20-26

Ulviyadipura., C. J. Hutabarat, Pinandoyo. 2017. Pengaruh Penambahan Ekstrak Buah Nanas pada Pakan Buatan Terhadap Tingkat Pemanfaatan Pakan, Pertumbuhan dan Kelulushidupan Benih Ikan Bawal Air Tawar (Colossoma macropomum). Pena Akuatika. 16 (1): 1 - 21

Utami, I.K., K. Haetami dan Rosidah. 2012. Pengaruh Penggunaan Tepung Daun Turi Hasil Fermentasi Pakan Buatan terhadap Pertumbuhan Benih Bawal Air Tawar (Colossoma macropomum Cuvier). J., Perikanan dan Kelautan. 3(4) : 91-100.

Widyasunu, C. A., I. Samidjan dan D. Rachmawati. 2013. Substitusi Tepung Ikan dengan Tepung Cacing (Lumbricus rubellus) dalam Pakan Butan Terhadap Pertumbuhan dan Efisiensi Pemanfaatan Pakan Kerapu Macan (Epinephelus fuscoguttatus)., J. of Aquaculture Management and Technology. 2(1): 38-51

Zhao, F., P. Zhuang., C. Song., Z. hong., Shia and Long, Z.Z. 2010. Amino Acid and Fatty Acid Compositions and Nutritional Quality of Muscle in the Pomfret, Pampus Punctatissimus., J. Food Chemistry., Elsevier., 224-227.

Zonneveld, N., E.A. Huisman, dan J.H. Boon. 1991. Prinsip-Prinsip Budidaya Ikan. Gramedia Pustaka Utama. Jakarta, 318 hlm. 